\title{
BOARD OF EDITORS OF THE AMERICAN JOURNAL OF INTERNATIONAL LAW
}

Charleg Noble Gregory, State University of Iowa.

Robert Lansing, Watertown, N. Y.

John Bassett Moore, Columbia University.

William W. Morrow, San Francisco, Cal.

LEO S. Rowe, University of Pennsylvania.

OscaR S. Straus, Washington, D. C.

Georae G. Wilson, Brown University.

Theodore S. Woolsey, Yale University.

David J. Hill, The Hague, European Editor.

\section{Managing Editor,}

JAMEs Brown ScotT, George Washington University.

\section{EDITORIAL COMMENT}

'JHF SECOND ANNUAL MEETING OF THE AMERICAN SOCIETY OF INTERNATIONAL LAW

The second annual meeting of the American Society of International Law was held at Washington, D. C., on April 24 and 25, at the New Willard Hotel, and was largely attended by members of the Society. The meeting was called to order on Friday, April 24, at 10 o'clock, by the president of the Society, the Hon. Elihu Root, who, after a brief address of welcome in which he set forth the aims of the Society and the progress made in the past year, delivered an address on "The Sanction of International Law." As this number of the Jocrnal contains the address in full it is unnecessary to quote any passages from it. It should be said, however, that aside from its intrinsic merits the address was important for the reason that his professional experience enabled the president to speak with peculiar authority on the sanction of municipal and international law. A lifetime spent in the court room necessarily familiarized him with the necessity and the form of sanction present in municipal law, and his position as Secretary of State enabled him - indeed, in a large measure required him - to analyze the sanc- 